\title{
MBA education at Debrecen University Faculty of Agricultural Economics and Rural Development
}

\author{
András Nábrádi, László Kárpáti and János Lazányi
}

\author{
University of Debrecen Faculty of Agricultural Economics and Rural Development
}

\begin{abstract}
Debrecen is the capital of the Great Hungarian Plain, the centre of many institutions, organizations and business companies just in the heart of Europe. It has provided an ideal setting for higher education since 1538. With this past of more than 450 years, the University of Debrecen is the oldest higher educational institution in continuous operation in Hungary based in the same city. Higher education in agriculture began in 1868, when the National Higher School of Agriculture was formed in Debrecen. The University of Debrecen has more than 26000 students, and more than 1700 instructors teach at the University, which has 13 faculties, 2 independent institutions, 20 doctoral schools and offers the widest choice of higher education. This outstanding intellectual centre, with a vast research and development capacity, has a growing importance in the economic and social development, cultural progress of the region. It devotes special attention to serving the needs of a knowledge based society more efficiently, and it strives to become the knowledge centre of the region, which also preserves traditions and values.
\end{abstract}

The Faculty of Agricultural Economics and Rural Development is an administrative, democratic, organizational framework to co-ordinate the education of its students and it is widely engaged in scientific research and extension activities. The Faculty was founded in 2000 to integrate agricultural economics and rural development into the University of Debrecen and to strengthen training in agribusiness; agricultural rural development; agricultural public administration; computing, statistics and business planning. The Faculty co-ordinates the organization of education, supervises the departments, widens the fields of research and participates in basic and postgraduate education, further education and extension work. The mission of the Faculty is to develop high-quality educational, research and development activities in the region which meet the demands of the nation, and contribute to the augmentation of national and international results via its creative activities.

The Faculty of Agricultural Economics and Rural Development has the goal of improving the economic performance of the agro-food sector through research designed to enhance and better understand Hungarian trade performance and policy options. In meeting this goal, it brings together a critical mass of researchers; increases the capacity to deliver agricultural policy research through research projects involving graduate students, and contributes to an informed debate on policy issues. The research activity of the Faculty of Agricultural Economics and Rural Development is focused on the stimulation of strategic thinking across the food chain. Efficient food system is sensitive to the needs of consumers, safe, environmentally responsive and has a high level of business integrity. Bringing together top food and agribusiness executives, academics, policy makers and other concerned stakeholders, it provides high quality, value-added services to meet the needs of local people and addresses the many challenges and opportunities facing food chain participants through leadership and innovation. Program planning, development and implementation are accomplished through six departments, which provide educational programs, responsible for research and development projects and take part in extension activities and write articles.

Department of Agricultural and General Economics Dr. Gábor Szabó, Professor

Department of Accounting and Finance

Dr. Zoltán Bács, Associate Professor

Department of Farm Business Management and Marketing Dr. András Nábrádi, Professor

Department of Rural Development and Resource

Management

Dr. Géza Nagy, Professor

Department of Management and Labour Science

Dr. Csaba Berde, Associate Professor

Department of Statistics and Agricultural Informatics

\section{Dr. Imre Ertsey, Professor}

The Faculty of Agricultural Economics and Rural Development has excelled in research, education and service in all parts of the food system from farm to fork. The core focus areas include economic education and knowledge transfer, effective food chain management, food safety and quality, contribution of technology to supply chains, economic and social development. Students come from all corners of Hungary, bringing a set of skills that helps their learning experience and creates a highly talented network whose alumni can rely on it as their careers progress. 


\section{Degree programmes offered by the Faculty of Agricultural Economics and Rural Development}

The aim of our agribusiness degree is to train experts who are competent to manage, plan and organize agricultural and related activities and to control them economically and financially. Graduates are also capable of working in agricultural education and research. With their professional knowledge, they are also qualified to work as economists in non-agricultural fields. Students are also trained to become chartered accountants, foreign trade agents and real estate agents. Specializations are available in computing; English, German or French professional communication studies; agribusiness communication; commerce-marketing; English or German technical translation; finance-accounting; entrepreneurial organization. Since 2001, a 10-day-long special study tour has been organized for the students, in the framework of which they gain practical insight into the work of EU institutions in Belgium, the Netherlands and Germany.

The agricultural rural development degree provides students with versatile training in effective agricultural production, recognizing the importance of biological diversity and environmental protection. Our graduates gain an overview of the characteristics of rural society and circumstances, and are capable of utilizing rural resources on an international scope. Furthermore, they can successfully co-operate in organizing programs and bids, especially within the European Union. Rural catering and tourism; agribusiness communication; grassland and resource management; extension and rural development; game management; environmental protection are the main offerings of specializations.

The Agribusiness Informatics degree provides the students with practical knowledge in the fields of informatics, agribusiness and agronomy. The EU accession of Hungary requires experts with new approaches and mentalities. In agricultural economics and rural development, there is an increased demand for computing experts with a high level of knowledge in agronomy and agribusiness. Opportunities for employment are ensured by the demands of the government, public administration and enterprises in finance, agricultural economics, food industry and commerce. Students can choose between two majors, which provide them with differentiated computing skills in economics and rural development or in agronomy and environmental informatics.

Students in the Agricultural Public Administration degree course not only complete agricultural studies, but also study law, finance, budgeting, and the rules of special and public administration. Only experts with this kind of qualification and extensive legal knowledge can effectively perform public administration and work for local authorities and other administrative bodies. In the post-secondary degree in computing, statistics and business planning, students complete economic, computing, business and language studies. The offered subjects and training guarantee students a wide range of employment possibilities. They may also continue their studies at university level. The manifestation of interest for the course also shows that a need has grown for experts with economics and computing knowledge, and that the chances for employment are good.

The postgraduate degree course in Human Resource Management runs for 4 semesters. Course participants are equipped with high level skills related to human resources. There is a strong need for this course both in Debrecen and Budapest. This need is supported by the high number of participants and the positive feedback received from the labour market.

The degree course in Entrepreneurial Management is available only in Debrecen. The type of education is correspondent. Three majors are offered within the degree course. The majors in Commerce and Marketing and EU Studies last for 4 semesters, while the MBA lasts for 5 semesters. The continuously high number of applicants proves that the major in Commerce and Marketing and the MBA answers the real needs of the labour market. The major in EU studies was launched in September 2002. The importance of this major will increase with the accession of our country to the EU.

\section{MBA Education}

MBA training at Debrecen Agricultural University was initiated by 0257-91/1 Tempus Joint European Project Grant. The project was coordinated by the Netherlands Institute for Management (RVB) Maastricht, under Dr. M.S.S. ElNamaki's project co-ordination. Participating institutions include University College in Dublin, Agricultural University in Wageningen and Debrecen Agricultural University. Minimum requirements established were a BSc (or equivalent) degree, an English certificate of language proficiency and one letter of reference from work supervisors or former teachers. Application requirements included a completed application form, Curriculum vitae, a certified copy of degree(s), an official copy of language knowledge certificate, a letter of recommendation and the receipt of registration fee payment. The academic year began on 1 September 1991, and project studies were carried out in small groups. Practical experience that had been gained before enrolment was taken into account and after the successful completion of the requirements students were granted MBA degrees.

The First Debrecen Executive MBA offered students to take full advantage of a wide range of expertise and experience in business, commerce and the opportunity to study with other agribusiness professionals supervised by an international network of professors. The first term of the programs focuses on key business skills through the core courses of Accounting, Business Finance, Decision Models, Economics, Leading and Managing, Marketing, Operations, Statistics and Strategy. The second year offers more special courses that are pragmatic and application-based for students' field of interest and goals, concentrating on Futures, Project Management, Food and Agribusiness 
Table 1: Programme of the first Debrecen Executive MBA

\begin{tabular}{|c|c|c|c|c|}
\hline Date & Title & Partner & Credit & Lecturer \\
\hline 1991 & & & & \\
\hline April & Basic English, & AUD & 0 & \\
\hline April & Principles of Economics & AUD & 0 & László Kárpáti \\
\hline April & Hungarian Accounting and Taxation I & AUD & 0 & András Kozma \\
\hline May & Advanced English & AUD & 1 & László Hunyadi \\
\hline May & Computer Application I. & AUD & 1 & László Mikecz \\
\hline June & Basic Business English & UCD & 1 & Elisabeth Tierney \\
\hline June & Advanced Business English & UCD & 1 & Elisabeth Tierney \\
\hline June & Computer Application II. & AUD & 1 & Tibor Tarnóczi \\
\hline July & Financial Accounting & UCD & 1 & Pearse Colbert \\
\hline July & Managerial Accounting & $\mathrm{UCD}$ & 1 & Pearse Colbert \\
\hline September & Industrial Economics & UW & 2 & Wim Heijman \\
\hline September & Macro Economics & UW & 2 & Ekko van Ierland \\
\hline September & Intro. International Economics & UW & 2 & Edwin Krouse \\
\hline November & Financial Management & UCD & 3 & Philip Bourke \\
\hline November & Organisational Theory & RVB & 2 & Albert Mills \\
\hline November & Human Resource Management & RVB & & Albert Mills \\
\hline $\begin{array}{l}\text { November } \\
1992\end{array}$ & Decision Making & RVB & & René Samson \\
\hline $\begin{array}{l}1992 \\
\text { January }\end{array}$ & Marketing Management & $\mathrm{UCD}$ & 2 & Anthony Cunningham \\
\hline January & Communication 1. & UCD & 1 & Elisabeth Tierney \\
\hline January & Communication II & AUD & 1 & Kálmán Rubovszky \\
\hline March & Quantitative Methods of Firm Planning & UW & 1 & J. van Niejenhuis \\
\hline March & Management Control & RVB & 2 & Kami Rwegasira \\
\hline March & Management Information Systems & RVB & 2 & Suresh Ankolekar \\
\hline May & Business Planning I. & UCD & 2 & E. Hession \\
\hline May & Business Planning II. & UCD & 2 & Aidan Kelly \\
\hline May & Hungarian Accounting and Taxation II. & AUD & 0 & András Kozma \\
\hline June & Hungarian Accounting and Taxation II. & AUD & 2 & András Kozma \\
\hline June & Hungarian Law & AUD & 1 & Katalin Sztipícs \\
\hline July & International Business & RVB & 1 & Rene Satuson \\
\hline July & International Marketing & RVB & 1 & Ger Bos \\
\hline July & International Finance & RVB & 2 & Kami Rwegasira \\
\hline September & International Law & UW & 1 & M. van der Velde \\
\hline September & Economics of Natural Resources & UW & 2 & Jakob Krabbe \\
\hline September & Technique of Foreign Trade & AUD & 1 & Gizella Zajácz \\
\hline November & Economics of Entrepreneurship & AUD & 3 & \\
\hline August & Hungarian Law & AUD & 1 & Katalin Sztipícs \\
\hline August & Entrepreneur Law & AUD & 1 & János András \\
\hline August & International Law & UW & 2 & M. van der Velde \\
\hline October & Hungarian Accounting and Taxation & AUD & 2 & András Kozma \\
\hline October & Technique of Foreign Trade & AUD & 1 & Gizella Zajácz \\
\hline October & Banking and Trade & AUD & 2 & Gizella Zajácz \\
\hline $\begin{array}{l}1993 \\
\text { January }\end{array}$ & Field Attachment & RVB, & & \\
\hline February & Field Attachment & $\mathrm{UCD}$ & 8 & \\
\hline March & Field Attachment & UW & & \\
\hline May & Thesis and Final Examination & & & \\
\hline
\end{tabular}

One credit $=15$ hours classroom or equivalent ( 1 week lecturing)

$\mathrm{UW}=$ University of Wageningen, The Netherlands

$\mathrm{RVB}=$ Netherlands International Institute for Management, The Netherlands

$\mathrm{UCD}=$ University College in Dublin, Ireland

AUD $=$ Agricultural University of Debrecen, Hungary

Management, Small and Medium size Enterprises Management, and International Trade of Farming Products. The financial management course discussed revenue maximization strategies and tactics that improved the profitability of businesses. Marketing Management was focused on marketing decision-making of agribusiness firms, with emphasis on the formulation of strategic marketing plans. Marketing research and analysis were based on marketing plans. The course deals with the use of futures, options and other instruments for marketing, risk management and investment purposes. Emphasis was placed on the development and implementation of trading strategies and on the policy of corporate governance framework necessary to support effective risk management. The theoretical studies consisted of economics, production economy, business analysis and planning, business management, agricultural policy, market strategies, project planning and evaluation, methods of empirical social research. The courses were built on a strong analytical foundation, ensuring that students acquire the functional skills and tools required in business environment.

The First Debrecen Executive MBA was intended for personnel who have at least five years experience in the management of food or at an agribusiness company, and who have been identified as potential candidates for future top level management positions. The goal of the program was to provide a global view of issues, broad perspectives and management skills on analysis of economic and policy issues relevant for food and agribusiness management with emphasis on the economic and policy environment of the region.

The First Debrecen Executive MBA course was assessed on the dynamic relationship between strategy and competition. Food, agribusiness and other cases were used to explore the development and implementation of strategies requiring the application of conceptual, analytical, problem identification, and problem solving skills to develop organizational strategy. In addition, the program allowed participants to work on a supervised research project, which involved the completion of a bibliography, the organization of materials, the selection of suitable problems, an understanding of related literature, the selection of appropriate procedures, formulation of a plan, collection and organization of data, investigating and the 
writing the thesis. The First Debrecen Executive MBA was implemented according to the time schedule provided in Table 1. Exams were held in different lecturing subjects and the names of participants are mentioned in Table 2. In the light of their excellent results, a second program was initiated with the same consortium to continue MBA training in Debrecen. From 1990 to 1994, with the financial help of Tempus Joint European Project Grant, 35 students received MBA degrees.

Table 2: Participants of the First Debrecen Executive MBA Programm

\begin{tabular}{|l|l|l|}
\hline Zoltán Babos & Béla Bártfai & Miklós Bencze \\
Csilla Boros & András Csizmazia & Sándor Erdei \\
Ferenc Falucskai & Péter Fehér & László Kárpáti \\
István Lányi & János Lazányi & András Nábrádi \\
István Nádai & Lajos Nagy & Mária Ujhelyi \\
\hline
\end{tabular}

\section{MBA training organised by the Centre of Agricultural Sciences}

The University of Debrecen, Centre of Agricultural Sciences (UDCAS) has established the Postgraduate Training of Corporate Studies on 1 September 1998. This course still exists at the University. During this period, the curriculum has changed twice and its name has also changed to Postgraduate Training in Entrepreneurship. The University Council decided to continue this training in the future. It contains four specialisations: commerce and marketing management, human resource management, European studies and (Masters Business Administration) MBA. In 1998, the training started in Budapest, in a rented building managed by the International Organisation of Hungarian People, and the first graduating class received its diploma in June 2000. The total number of students receiving their diplomas was more than 100 .

In the Budapest facility, there were 2 offices and 5 classrooms for students. The biggest classroom provided space for 110 students, four rooms for 50-60 students and the smallest one for 15 students. A theatre-room (for 250 persons) was also available for teaching. In the building, a canteen and a buffet were available for students. This place provided suitable relaxation and teaching conditions. It was enough for maximum 240 students, 4 full-time employees and guest lecturers. The library of the University of Economics and State Administration was available for students. Because of the Hungarian demographical situation and its labour market, the number of students has increased year by year. In its activities within the scope of this program, UDCAS assists in solving a social problem in Hungary, by giving a second diploma for those who cannot find gainful employment. The increased interest in this training could be related to the fact that graduated students were satisfied with the quality of the training.

The aim of this training was to provide knowledge for managers in economics, domestic and international marketing, finance, human resource management and EC management, so they would be able to work as experts in different fields of business. These tendencies met the requirements of international trends. The experience of the 5 academic years verified the success of the training, as did the fact that, in Hungary, several universities and 19 private schools began to offer this kind of managerial training. Originally, students came from different parts of Hungary to Budapest to study. And now, since 2005, they come to Debrecen for this program.

The managerial training course now situated at the Faculty of Agricultural Economics and Rural Development operates within the University of Debrecen, Centre of Agricultural Sciences. This Faculty guarantees the course sufficient financial direction and control. In this programme, we involve subjects, which have already proved themselves as high quality through their having been utilized in the graduate programme, and on the basis that the responsible lecturers of each subject are highly experienced. More than $50 \%$ of the lecturers are from the University of Debrecen, Centre of Agricultural Sciences and the remaining part are from other universities.

The aim of the training is to allow for graduated experts to have suitable knowledge in economics, marketing international business, finance, human resource management and EC management, so they will be able to work as managers in different fields of business. Students should be prepared to find good jobs, to modify jobs and to be able to come up to the changing requirements in the labour market.

Named qualifications in the diploma include the following:

- Certificated expert of corporate economics

- Certificated Postgraduate Training of Entrepreneurship with MSC.

- Basic certification

- Expert of corporate economics

Postgraduate Training of Entrepreneurship with collegelevel Basic certification, within one of the following specialisations:

- Commerce and marketing manager

- Human manager

- MBA

- European Studies

Conditions of participation in the program are university or college diplomas. The training period is $4+1$ semesters. The minimum number of attended lectures for receiving certification is 500. Main education fields contain four specialisations: commerce and marketing management, human resource management, European studies and (Masters Business Administration) MBA. The number of subjects in each specialisation is as follows:

Commercial and marketing manager 20 subjects,

Human manager 19 subjects,

MBA 21 subjects,

European studies 20 subjects. 
Requirements of the diploma: Thesis must be written, where theoretical knowledge is translated into practical life. The content and form of this work must meet the requirements for a university diploma.

Final examination: According to Hungarian regulations, the final exam includes a written thesis and its defence in the presence of a final examinations board. The precondition for taking part in the final exam is to fulfil the requirements and the obligations of the mid-term exams. The qualification of the certificate is determined by the mark given at the thesis defence and the average of all other examination marks. The result of the final examination is the same as the mark for the thesis.

\section{Self assessment of the MBA executive training at UDCAS}

The guidelines of self assessment, including requirements as regards content and form, were provided by the Hungarian Accreditation Committee. The self assessment of the business training at the University of Debrecen Centre of
Agricultural Sciences Institute of Agricultural Economics and Rural Development was prepared on the basis of these guidelines. The institution began its educational activity in the 1998/99 academic year. It provides professional postgraduate training; postgraduate diploma is issued by the University of Debrecen, since this executive training is almost the same as the business studies course of the University being under an accreditation process at present.

Admission requirements to the MSc degree training. Duration of the training: 4 semesters. Type of training is correspondence, altogether 520-530 contact hours, 2 contact days per week. There are 5 specialisation possibilities in the 1st year: commerce and marketing management, human resource management, top management, economics. From the 2nd year, there is a possibility to choose the MBA specialisation as well. The teaching structure of the training is similar to that of the postgraduate course: "Corporate Management" of the former Debrecen Agricultural University, launched in 1977. Taking into consideration the current interests of students, there are three specialisations running at present: Commerce and marketing manageent, Human resource management and MBA.

Table 3: Number of contact hours and method of examination at MBA training First year

\begin{tabular}{|c|c|c|c|c|c|}
\hline \multirow[t]{2}{*}{ Subject } & \multicolumn{4}{|c|}{ Semesters } & \multirow[t]{2}{*}{ Total } \\
\hline & 1. & 2. & 3. & 4. & \\
\hline $\begin{array}{l}\text { Managerial communication + MIS } \\
\text { Microeconomics } \\
\text { Basic Methodology } \\
\text { Sociology } \\
\text { Macro- and International Economics } \\
\text { Managerial decisions + TQM } \\
\text { Advanced Econometric Methods } \\
\text { Management } \\
\text { Corporate Finance } \\
\text { Human Resource Management } \\
\text { Marketing } \\
\text { Business Planning } \\
\text { Strategic Management } \\
\text { International Business } \\
\text { Applied Psychology } \\
\text { International Finance } \\
\text { Accounting, Taxation } \\
\text { Law } \\
\text { Project work } \\
\text { Total number of hours } \\
\text { Number of examinations } \\
\text { Optional: } \\
\text { Basic Business English } \\
\text { Advanced Business English } \\
\text { Computing }\end{array}$ & $\begin{array}{l}110 \\
4 \\
20 \\
- \\
20\end{array}$ & $\begin{array}{l}30 \mathrm{SZ} \\
30 \mathrm{~K} \\
30 \mathrm{~K} \\
30 \mathrm{~K}\end{array}$ & $\begin{array}{l}20 \mathrm{~K} \\
30 \mathrm{SZ} \\
30 \mathrm{~K} \\
20 \mathrm{~K} \\
30 \mathrm{~K}\end{array}$ & $\begin{array}{l}20 \mathrm{~K} \\
20 \mathrm{~K} \\
20 \mathrm{~K} \\
30 \mathrm{SZ} \\
30 \mathrm{~K} \\
(20) \\
120 \\
4 \\
- \\
20 \\
-\end{array}$ & $\begin{array}{l}30 \\
30 \\
30 \\
20 \\
30 \\
30 \\
\\
30 \\
20 \\
30 \\
30 \\
20 \\
30 \\
20 \\
20 \\
20 \\
30 \\
30 \\
40 \\
480 \\
17 \\
40 \\
40 \\
40\end{array}$ \\
\hline
\end{tabular}

A: Acceptance GY: Practical exam K: Normal exam SZ: Raised level exam 
Table 3: Number of contact hours and method of examination at MBA training Second year

\begin{tabular}{|c|c|c|c|c|c|}
\hline Subject & 1 & 2 & 3 & 4 & Total \\
\hline Psychology training & $24 \mathrm{~A}$ & & & & 24 \\
\hline Managerial Communication & $28 \mathrm{~K}$ & & & & 28 \\
\hline Microeconomics & $24 \mathrm{~K}$ & & & & 24 \\
\hline Basic Methodology & $24 \mathrm{~K}$ & & & & 24 \\
\hline Sociology & $24 \mathrm{~K}$ & & & & 24 \\
\hline Macro- and International Economics & & $28 \mathrm{SZ}$ & & & 28 \\
\hline Managerial Decisions & & $24 \mathrm{~K}$ & & & 24 \\
\hline Advanced Econometric Methods & & $20 \mathrm{~K}$ & & & 20 \\
\hline Management & & $28 \mathrm{SZ}$ & & & 28 \\
\hline Law & & $20 \mathrm{~K}$ & & & 20 \\
\hline Corporate Finance & & & $24 \mathrm{SZ}$ & & 24 \\
\hline Humanity & & & $24 \mathrm{~K}$ & & 24 \\
\hline Marketing & & & $24 \mathrm{~K}$ & & 24 \\
\hline Business Planning & & & $20 \mathrm{GY}$ & & 20 \\
\hline Strategic Management & & & $24 \mathrm{~K}$ & & 24 \\
\hline International Business & & & & $24 \mathrm{GY}$ & 24 \\
\hline International Finance & & & & $20 \mathrm{~K}$ & 20 \\
\hline Accounting, Taxation & & & & $24 \mathrm{~K}$ & 24 \\
\hline EU studies & & & & $32 \mathrm{~K}$ & 32 \\
\hline Public Speaking & & & & $24 \mathrm{GY}$ & 24 \\
\hline Project work & & $20 \mathrm{GY}$ & $20 \mathrm{GY}$ & & 40 \\
\hline Total number of hours & 124 & 144 & 136 & 124 & 524 \\
\hline Number of examinations & 4 & 6 & 6 & 5 & 21 \\
\hline Optional: & & & & & \\
\hline Basic Business English & & $24 \mathrm{GY}$ & $20 \mathrm{~K}$ & $20 \mathrm{~K}$ & 24 \\
\hline Advanced Business E. & & $20 \mathrm{~K}$ & & & 60 \\
\hline
\end{tabular}

A: Acceptance GY: Practical exam K: Normal exam SZ: Raised level exam

\section{Course descriptions}

Management Communication: helps students to attain the Basic forms, levels and models of communication in theory and practice, to develop their own communication abilities orally and in written form, to get acquainted with the difference between everyday communication and management communication and to get acquainted with the technical and tactical elements of the everyday communication forms. This subject builds on previous communication knowledge and existing practice.

Course outline:

- On the basis of the social field-theory: the development of communication

- Relationships, related to socialisation, developing a personality.

- Creating relationships, and content and communicational techniques.

- Rules and types of conviction and argumentation.

- Know-how of negotiation, types of two-, and manysided negotiations
- Sources of conflict, conflict management possibilities and rules

- Structure of a speech, its content and rhetoric elements, rules

- Leading negotiation and the comparative utilisation possibilities of a talk

- Leaders' meetings, rules of leading conferences

- Media discussions, interviews, making report with leaders, rules of relations with the media.

Practices are built on the elaboration of lectures, presupposing that the student prepares for the practise on the basis of the material of the lecture. The proportion is $4: 1$ Control will be done during the lectures with the help of roleplaying and public special scoring. Oral exam is compulsory if someone is not satisfied with the offered mark or if his/her given points are less than the minimum of 60 points. Final assessment: Oral exam, according to the points, written above.

Microeconomics: Through giving lectures on microeconomics, developing students may utilise their theoretical knowledge, to solve actual problems including 
how to influence demand and supply, outcome and prices. The theory of demand and utility. Business organisation and income. Analysis of costs. The competitive supply. Imperfect competition: monopoly and regulation. Imperfect competition and antitrust policy. Income and the standard of living. The theory of production and marginality. Determination of input factors beforehand. Rent of lands and other natural resources. Wages, salaries and the labour market. Interest, profit and capital. Final assessment is through written exams, with marking between $1-5$.

Advanced Econometric Methods: Examining the relations between the different fields of economic life by making models and to evaluate the results reliably. All the methods will be shown using computers. Course outline:

- Presentation and utilisation of multivariable methods.

- Econometric examinations with production functions.

- Utilisation fields of linear programming models

- Nonlinear programming case studies

- Network analysis case studies

- Utilisation possibilities of other econometric- and operations research methods (simulations, dynamic programming, game theory).

Final assessment: written exam

Basic Methodology: Basics of mathematics, statistics and operational research by practical examples. Building up Basic knowledge for the course of Advanced Econometric Methods.

Course outline:

- Basics of the theory of functions, review on the functions of examination methods

- Basics of probability calculation and statistics, Correlation and regression

- Essence of modelling, possibilities of creating and solving models

- Types of mathematical programming models

- Basics of network analysis

- Possibilities of acquiring information and their utilisation

Final assessment: written exam.

Sociology: The aim of the subject is to learn the methods of sociology (methods of epistemology) and the characteristics of theory development. It gives an opportunity to look into the social-historical conditions of the origin of sociology by reviewing schools of thought and significant personalities. In the middle of the semester, we will discuss the fundamental importance of social structure, which influences social change. At the same time, the theory behind how the institutionalizing process works is explained. The development of social inequality systems and the role of social inequality dimensions in Hungarian social history. In the second part of the lectures, students are acquainted with the sociological view of culture, with an emphasis on its integrating norm creating and norm interposition importance. Furthermore, the possibilities for using sociocultural analysis for different statuses and roles existing in society are also discussed.

Course outline:

- The examination methods of sociology, societal view of sociology

- The history of sociology (schools, ambitions, personalities)

- The influence of culture on economic development (Károly Polányi and his economic integration, Max Weber about the Protestant ethic as the "ghosts" of capitalism)

- Social structure, structure opinions (theories of social classes and social strata)

- Social mobility and migration

- Institutionalizing processes of society, social institutions

- Inequality structure of society (status, income, cultural differences and inconsistency)

- Sexual (male, female) roles, role conception and their cultural interpretation

- Social importance of human lifecycle: childhood, old age - cultural interpretations

- The history of cultural thinking

- Culture theories: philosophic conception, anthropologic-, psychoanalytic- and sociological interpretations

- Following regulations, norms, values and patterns tradition and innovation in culture

Final assessment: Oral exam (Commerce and marketing course, MBA) Written exam (Human Resource Management Course).

Humanity: Getting acquainted with the philosophic, psychoanalytic, anthropologic and sociological approach of culture, concepts and interrelations of social subsystems (politics, economy, culture)

Course outline:

- The concept of culture: different aspects of the concept of culture (ethnographic, symbolic, anthropologic, information, philosophic and psychoanalytic aspects)

- The "origin" of culture

- Socialisation, learning, tradition, selective patterns

- Social integration: socialisation, learning, tradition, following patterns

Final assessment: Oral exam.

Management Decision-Making: Students are acquainted with basic concepts and most important questions of this discipline. H. Simon (Nobel Prize winner) and P. Drucker played important roles in this discipline. Theory and practice of acceptable, good and optimal decisions. Decisions based on objective facts und intuitions. Managers' way of thinking. Distinction between acceptable, good and optimal decisions.

Final assessment: Oral exam 
Law: Basics of the legal system, legal regulations and characteristics of an operating legal system. Overall knowledge enabling students to learn special areas of law and interpret legal problems.

Course outline:

- Elements of legal theory, categories of legal development

- Determination of the legal system, basic processes

- Elements of legal notions (effectiveness, validity, legal entity)

- Forms of legal responsibility

- Parts of the legal system

- Theoretical and political basics of constitutional law development for the Constitution

- Organisational forms of Constitution, legal frames of executive power

- Parliament, Government, President of the Republic, etc.

- Personal rights

- Other areas of common law (law of public administration, financial law)

- Basic categories of criminal law. Introduction to the general part, specialised parts

- Basic principles of criminal procedures. Organisations in criminal law

- Civil law I. System of civics, laws of individuals

- General characteristics of ownership and contractual law, family law

- Civil law II. Law of enterprises

- Sociological characteristics of administering law and legislation

Final assessment: Oral examination

Marketing: By the end of the course students will obtain an overall knowledge in marketing management and the basic methods of marketing planning

Course outline:

- Marketing and market conditions

- Basics of marketing:

- Product policy

- Price policy

- Channel management

- Advertisements

- Functioning of the marketing system

- Marketing information system

- International marketing

- Marketing strategy

- Theoretical and practical questions of marketing planning

Final assessment: Evaluation of the marketing plan. The marketing plan has to include a study on a real marketing activity of an existing company, thus vocational practice is obligatory

Business Planning: The basics of business planning will be introduced to students. Each student will prepare a business plan on a PC with the guidance of the course leader on the data of an existing company.
Course outline:

Theoretical and practical basics of planning, business plan Managerial summary

Overall introduction of the company

Connections of the company (environmental analysis)

Leadership and structure of organisation

Technological, organisational plan, products and services

Marketing plan, strategic plan on financial planning

Appendices to the business plan

Relevant analyses in connection with the business plan

Final assessment: Evaluation of the business plan

International Finance: to introduce the international statement of expenditures and its legal aspects, the balance of payment, international exchange rates to explain international money and capital market, international monetary institutions, the basics of EMU and EURO.

Course outline:

- convertibility, foreign exchange regulations, balance of payment - rate of exchange, related measures

- international money and capital market, credit system

- international statement of expenditures, methods of payment

- international monetary institutions

- European Monetary Union, introduction of EURO

- Types of foreign trade transactions

- Realisation of foreign trade transactions

Final assessment: Written examination

Rhetoric: Objectives of the course are to make students realise the theoretical and practical norms of particular Hungarian public parlance, word of mouth, construction and the sound of living speech and public standard. Furthermore, to make students realise and to accustom them to speaking to the public, special requirements of public communication arising from situations, the particular manner of speaking as regards partner/s and the subject of conversation, conscious manner of speaking and an appropriate attitude to partners' positions, social and scientific activities. This course provides both theoretical and practical knowledge that are necessary for people wishing to communicate with the public either in writing or oral forms.

Course outline:

- Rhetoric as a multidisciplinary and auxiliary science

- Basics of rhetoric and communication

- Language and speech

- Structural parts in public speech, preparation of speeches

- Principals of good drafting as regards sounding

- Main methods of oral and written communication, main requirements of oral presentations. Preparation of a presentation.

- Presentation of a speech, speaker on the speaker's platform, behind the microphone and camera.

- Up-to-date style of speaking. Speaking norms

- Basics of clear speaking

Final assessment: Practical mark in MBA specialisation 